\title{
EFEKTIFITAS KOMUNIKASI ANTAR PRIBADI PENGGIAT LINGKUNGANTERHADAP PERILAKU PENGELOLAAN SAMPAH SISWA
}

\author{
Ester Junita Tampubolon \\ Universitas Sumatera Utara \\ ester_junita_fisipusu@yahoo.com
}

\begin{abstract}
Abstrak
Tujuan dari penelitian ini untuk mengetahui keefektifan Komunikasi Antarpribadi yang terjalin antarapenggiat lingkungan terhadap siswa dan untuk mengetahui hambatanhambatan yang di hadapi penggiat lingkungan ketika melakukan Komunikasi Antarpribadi terhadap siswa dalam mengubah perilakupengelolaan sampah dikalangan siswa.Penelitian ini bersifat deskriptif kualitatif dengan metode wawancara mendalam dan observasi partisipan. Jumlah informan sebanyak enam orang siswa dan satu orang penggiat lingkungan. Teknis analisis data yang digunakan adalah teknik pendekatan kualitatif dan analisis deskriptif dengan metode studi kasus yang merujuk pada metode analisis interaksi Miles dan Huberman. Hasil penelitian menunjukkan keefektifitasan komunikasi antarpribadi yang dilakukan oleh penggiat lingkungan terhadap siswa dikembangkan melalui kualitas diri yang mencakup keterbukaan, empati, pendukungan, kepositifan, dan kesetaraan. Penggiat lingkungan dapat mengatasi hambatan yang terjadi ketika berkomunikasi dengan siswa melalui pengembangan hubungan dimulai dari perkenalan, keterbukaan dan kejujuran.
\end{abstract}

Kata kunci: Komunikasi Antarpribadi, Penggiat Lingkungan, Siswa

\section{Asbtract}

The purpose of this study to determine the effectiveness of Interpersonal Communication established between environmental activists against students and to identify any obstacles in the face of environmental activists when Interpersonal Communication on students in changing the behavior of waste management among students. This research is descriptive qualitative in-depth interviews and participant observation. The number of informants as six students and one environmental activists. Technical data analysis techniques used are qualitative and descriptive analysis with case study method refers to the method of interaction analysis Miles and Huberman. The results showed the effectiveness of interpersonal communication conducted by environmental activists against students developed through qualities that include openness, empathy, support, positivity, and equality. Environmental activists can overcome the obstacles that occur when communicating with students through the development of relationships starting from the introduction.

Keywords: Interpersonal Communication, Environmental Activists, Students 


\section{PENDAHULUAN}

Berkomunikasi efektif berarti bahwa komunikator dan komunikan sama sama memiliki pengertian yang sama tentang suatu pesan. Rakhmad (2004:159)

menyatakan bahwa komunikasi yang efektif bila pertemuan komunikasi merupakan hal yang menyenangkan bagi komunikan. Menurut Effendy (2007: 219) Komunikasi yang efektif adalah komunikasi yang menimbulkan sikap, opini, maupun perilaku. Berdasarkan pendapat tersebut, melalui sikap, opini, dan perilaku yang ditunjukkan oleh komunikan dapat dinilai bahwa komunikator sudah melakukan komunikasi yang efektif. Komunikasi yang efektif tentu menimbulkan efek yang mempengaruhi komunikasi tersebut

Hal ini juga dilakukan oleh seorang Penggiat Lingkungan dalam menyampaikan informasi ke sekolah-sekolah terhadap siswa tentang pengelolaan sampah. Penggiat Lingkungan sebagai komunikator dapat menjalin pertemuan yang menyenangkan bagi siswa sebagai komunikan dalam kegiatan pengelolaan sampah disekolah.

Sering kita berpikir bahwa sampah adalah buangan yang tidak berguna dan harus dibuang bahkan dibakar. Hal ini perlu di ubah dan di luruskan. Setiap anggota keluarga harus diberi pemahaman dan penyadaran tentang pengelolaan sampah yang benar, sehingga terbentuk karakter pola hidup bersih dan sehat. UndangUndang No. 18 Tahun 2008 tentang Pengelolaan Sampah pada pasal 29 menyatakan bahwa setiap orang di larang membakar sampah yang tidak sesuai dengan persyaratan teknis pengelolaan sampah. Artinya, sampah tidak boleh dibakar. Hal ini di pertegas lagi dengan adanya sanksi administrative bagi yang melanggar ketentuan tersebut. Hal ini menunjukkan bahwa sampah perlu dikelola karena sampah juga dapat bermanfaat apabila dikelola dengan baik dan benar.

Penanganan sampah dengan system kumpul-angkut-buang yang memindahkan masalah diwilayah lain perlu segera dibenahi.Berdasarkan Peraturan Pemerintah Nomor 81 Tahun 2012 tentang Pengelolaan Sampah Rumah Tangga dan Sampah Sejenis Rumah Tangga pada Bab pendahuluan menyebutkan, sampah merupakan konsekuensi dari adanya kegiatan manusia yang begitu beragam. Artinya, sampah timbul dari perbuatan manusia sebagai akibat dari kegiatannya sehari-hari sehingga harus ditangani dengan serius pengelolaannya karena menyangkut hajat hidup orang banyak. Soemarwoto (1991: 29) mengatakan setiap kegiatan manusia pasti menghasilkan sampah. Jumlah atau volume sampah berbanding lurus dengan tingkat konsumsi barang yang kita gunakan sehari-hari, dan jenis sampah juga sangat tergantung dari material yang kita konsumsi.

Pengelolaan lingkungan hidup dapatlah diartikan sebagai usaha secara sadar untuk memelihara atau memperbaiki mutu lingkungan agar kebutuhan dasar kita dapat terpenuhi dengan sebaik-baiknya (Soemarwoto, 1991: 73). Hal ini dapat dilakukan dengan mengubah cara pandang dan perilaku kita terhadap alam. Perubahan tersebut dilakukan dengan menciptakan hidup peduli lingkungan melalui perilaku yang sadar akan pengelolaan sampah.Komunikasi sebagai alat untuk mengubah sikap dan kelakuan bukanlah pekerjaan yang mudah karena hal ini terdapat dalam sifat manusia.Kepedulian ini tidak berhenti pada batas kesadaran saja tetapi harus sampai pada tindakan (action) yang juga menjadi perilaku hidup baru. 
Peduli terhadap lingkungan dapat tercapai dengan pengetahuan terhadap lingkungan. Pengetahuan ini dapat diperoleh melalui informasi yang diberikan oleh orang lain. Informasi tersebut perlu disosialisasikan oleh penggiat lingkungan. Terkadang kita lebih percaya kepada seseorang yang sudah melakukan terlebih dahulu dan ada keberhasilan yang terlihat dalam program tersebut. Informasi yang disampaikan haruslah tepat sasaran dan dilakukan dengan komunikasi yang efektif, sehingga komunikasi itu terjadi secara berkelanjutan dan ada tindak lanjutnya. Komunikasi yang dilakukan Penggiat Lingkungan terhadap siswa dapat dikatakan efektif jika siswa memiliki pengetahuan tentang pengelolaan sampah dapat tercapai dengan baik dalam waktu tertentu dan tidak sebatas pengetahuan saja, namun ada action nya.

Komunikasi antarpribadi merupakan suatu proses sosial dimana orang -orang yang terlibat di dalamnya saling mempengaruhi. Melalui komunikasi antarpribadi,Penggiat Lingkungan menyampaikan pesan dan informasi kepada siswa untuk berperilaku peduli lingkungan sehingga mampu melakukan pengelolaan sampah. Menyampaikan pesan tersebut dapat dilakukan dengan komunikasi yang rutin. Penggiat Lingkungan melakukan pendekatan kepada siswa supaya siswa berperilaku peduli terhadap lingkungan. Penggiat Lingkungan memberikan pengarahan bagaimana perilaku yang peduli lingkungan sehingga siswa merasa bahwa peduli lingkungan itu sangatlah penting dan harus.

Bentuk komunikasi yang dilakukan adalah komunikasi antarpribadi antara Penggiat Lingkungan terhadap siswa. Pendekatan dengan komunikasi antarpribadilebih merasakan dan melihat dengan jelas apa yang menjadi hambatan atau hal-hal apa yang dapat mempermudah proses penyampaian pesan dalam berkomunikasi kepada siswa dan bagaimana reaksi siswa terhadap informasi, pesan, gagasan yang disampaikan Penggiat Lingkungan kepada siswa.

\section{METODOLOGI PENELITIAN}

Pendekatan yang digunakan adalah pendekatan penelitian deskriptif kualitatif. Penelitian deskriptif kualitatif merupakan penelitian yang termasuk dalam jenis penelitian kualitatif. Convelo (1993: 71-73) mengatakan, penelitian deskriptif kualitatif dirancang untuk mengumpulkan informasi tentang keadaan-keadaan nyata sekarang yang sementara berlangsung. Lebih lanjut Convelo mengatakan penelitian deskriptif kualitatif adalah metode dalam meneliti status sekelompok manusia, suatu objek dengan tujuan membuat deskriptif, gambaran atau lukisan secara sistematis, faktual, dan akurat mengenai fakta-fakta atau fenomena yang diselidiki.

Pengumpulan data yang digunakan adalah dengan teknik purposive sampling. Metode pengumpulan data dilakukan melalui wawancara secara mendalam (indepth interview) terhadap satu orang penggiat lingkungan yaitu Paris Sembiring (Ps) dan enam orang siswa yang terdiri dari dua orang siswa yang duduk di kelas VII SMP yaitu Crisantono (Cr) dan Debby Anggraeny (Da), dua orang siswa kelas VIII SMP yaitu Benny Santoso (Bs) dan Ernawaty (Er), dua orang siswa kelas IX SMP yaitu Aini (An) dan Firmansyah Abadi (Fa).

Wawancara dilakukan pada saat diluar jam sekolah, pada saat jam istirahat sekolah, atau pada saat siswa mengikuti jam belajar ekstrakurikuler. Sebelum melakukan wawancara, penulis terlebih dahulu telah mempersiapkan konsep pertanyaan atau pedoman wawancara yang tidak diketahui oleh informan. 
Selain itu juga menggunakan metode observasi partisipan yang termasuk dalam kategori observer sebagai partisipan yaitu orang luar yang netral (outsider) yang bergabung dalam kegiatan pengelolaan sampah siswa dan berpartisipasi dalam kegiatan dan pola hidup tersebut sambil melakukan pengamatan. Sebelum melaksanakan pengamatan, penulis mengadakan pendekatan dengan informan sehingga terjadi keakraban antara penulis dengan informan.

Analisis data yang digunakan merujuk pada metode analisis interaksi Miles dan Huberman. Aktivitas analisis data meliputi tiga unsur yaitu reduksi data, penyajian data, dan penarikan kesimpulan. Tahap awal, penulisakan merangkum dan memilah-milah hal yang pokok dan penting, menganalisis hasil-hasil wawancara dan menyajikan dalam bentuk kata-kata berdasarkan teori yang digunakan untuk selanjutnya menarik kesimpulan.

\section{HASIL DAN PEMBAHASAN}

Komunikasi antar pribadi merupakan suatu proses sosial dimana orang-orang yang terlibat didalamnya saling mempengaruhi (Harapan, 2014: 4). Lebih lanjut, Harapan menjelaskan bahwa komunikasi antarpribadi merupakan pengiriman pesan-pesan dari seseorang dan diterima oleh orang lain, atau sekelompok orang dengan efek dan umpan balik yang langsung.Konteks antarpribadi banyak membahas tentang bagaimana suatu hubungan dimulai, bagaimana mempertahankan suatu hubungan dan keretakan suatu hubungan (West\& Turner 2011: 36).

Komunikasi antarpribadi dapat menjadi komunikasi yang sangat efektif dan dapat menjadi komunikasi yang sangat tidak efektif sehingga tidak ada komunikasi antarpribadi yang gagal atau berhasil secara total.

Keefektifan komunikasi antarpribadi dalam penelitian ini adalah lebih kepada perspektif humanistic yang mencakup lima kualitas umum yaitu keterbukaan, empati, pendukungan, kepositifan, dan kesetaraan. Kelima kualitas umum keefektifan komunikasi antarpribadi tersebut akan diuraikan sesuai dengan hasil temuan, sebagai berikut:

\section{Keterbukaan}

Komunikasi antarpribadi yang efektif harus terbuka dengan orang lain yang berinteraksi dengannya. Hal ini terlihat pada komunikasi yang dilakukan penggiat lingkungan terhadap siswa, dimana penggiat lingkungan lebih dahulu melakukan keterbukaan tentang dirinya, siapa dirinya, apa pekerjaannya, kegiatan apa yang dilakukannya sehubungan dengan pengelolaan sampah seperti diungkapkan penggiat lingkungan sebagai berikut:

"Awalnya, saya memperkenalkan diri saya, pekerjaan saya, kegiatan yang ingin saya lakukan di sekolah ini. Saat pertemuan pertama Saya berkomunikasi secara keseluruhan terhadap semua siswa melalui sosialisasi tentang lingkungan khususnya pengelolaan sampah. Melalui sosialisasi tersebut saya sampaikan bagaimana tentang pengelolaan sampah yang baik dan benar. Setiap pertemuan yang saya lakukan, saya memperhatikan reaksi siswa-siswa di sekolah ini. Seiring waktu berjalan, saya menemukan beberapa siswa yang memahami tentang pengelolaan sampah".

Keterbukaan dalam hal ini mencakup tiga hal penting yaitu aspek membuka diri, aspek kejujuran, dan aspek kepemilikan pikiran dan perasaan. Penggiat lingkungan harus membuka dirinya terlebih dahulu secara jujur tentang tujuan yang ingin 
dicapai dalam menyampaikan informasi tentang pengelolaan sampah. Selanjutnya, ketika keterbukan yang dilakukan dengan kejujuran, maka akan lebih mudah untuk menyampaikan pikiran dan perasaan seperti yang diinginkan.Membuka diri maksudnya adalah harus ada keinginan untuk menyampaikan informasi tentang dirinya sendiri. Keterbukaan dalam pertukaran informasi antarpribadi dan pribadi harus dilakukan secara timbal balik agar komunikasi antarpribadi berjalan efektif.

$$
\text { Hasil wawancara tersebut }
$$

menunjukkan adanya persamaan jawaban antara penggiat lingkungan dan informan siswa An, yaitu dalam hal keterbukaan untuk menceritakan uneg-unegnya tentang perilaku orang lain yang tidak peduli lingkungan dalam hal pengelolaan sampah. Sejalan dengan informan An, hasil wawancara terhadap informan Bs juga berpendapat sama tentang keterbukaan kepada penggiat lingkungan, sepertiberikut ini:

“....Orangnya terbuka dan ramah, tidak pelit dengan ilmu serta cepat akrab kalau ngobrol dengan bapak itu".

Keterbukaan informan siswa Bs terhadap penggiat lingkungan juga berkaitan dengan pengelolaan sampah. Siswa ini mau membuka dirinya untuk berkomunikasi secara akrab dan terbuka kepada penggiat lingkungan karena penggiat lingkungan telah melakukan komunikasi antarpribadi yang terbuka dan adanya kejujuran yang ditunjukkan oleh penggiat lingkungan ketika melakukan komunikasi terhadap siswa.

\section{Empati}

Empati dengan seseorang adalah merasakan seperti yang dirasakan orang lain. Merasakan perasaan yang sama dengan cara yang sama memungkinkan kita memahami secara emosional dan intelektual apa yang dialami orang lain. Semakin banyak yang kita ketahui tentang seseorang maka semakin besar kemampuan kita untuk merasakan apa yang dirasakan seseorang. Berempati terhadap orang lain berarti turut merasakan apa yang dirasakan oleh orang lain tersebut secara keseluruhan apa adanya namun tanpa menghilangkan identitas diri.

Hasil wawancara menunjukkan bahwa empati yang dilakukan penggiat lingkungan terhadap siswa saat siswa mulai mengungkapkan apa yang dirasakannya ketika melihat orang lain yang tidak peduli lingkungan, maka siswa menyampaikan kepada penggiat lingkungan supaya dapat merasakan perasaannya, dalam hal ini mengenai pengelolaan sampah. Siswa menginginkan agar penggiat lingkungan berempati terhadap dirinya melalui reaksi atau jawaban yang di ungkapkan penggiat lingkungan terhadap siswa, seperti yang diungkapkan informan Da berikut ini:

“....misalnya kalau ada orang yang buang sampah sembarangan, kalau ada orang yang bakar sampah, apalagi orang yang naik mobil itu kak sering kali buang sampahnya dari mobil, itukan enggak baik kak. Aku sering ceritakan sama pak Paris tentang itu. Bapak itu senyum aja dan bilang, kalau aku jangan begitu".

Hasil temuan wawancara terhadap siswa menunjukakan bahwa informan siswa mengungkapkan perasaannya kepada penggiat lingkungan tentang pengelolaan sampah agar mendapatkan empati dari penggiat lingkungan, hal ini dapat dilihat dari hasil wawancara terhadap informan $\mathrm{Da}$, sebagai berikut:

"Kalau cerita sama Pak Paris, pasti dibilang Bapak itu, kita jangan mau serupa dengan orang yang perilakunya nggak baik tentang lingkungan, justru aku harus menunjukkan sikap yang peduli lingkungan". 
Sesuai dengan hasil temuan tersebut, dapat dilihat bahwa informan siswa sangat mengharapkan penggiat lingkungan dapat merasakan apa yang dirasakan informan siswa ketika melihat ada orang-orang yang tidak peduli terhadap lingkungan khususnya terhadap pengelolaan sampah. Perasaan kesal yang dirasakan siswa diharapkan dapat juga dirasakan oleh penggiat lingkungan. Hal ini dapat ditunjukkan melalui hasil wawancara terhadap informan penggiat lingkungan (Ps) sebagai berikut:

"Tentang kegelisahan dan keresahan mereka buk, melihat perilaku orangorang yang tidak bertanggung jawab menjaga lingkungan, misalnya orang yang suka bakar sampah, orang yang membuang sampah sembarangan, bahkan ketika mereka melihat ada orang yang membuang sampahnya dari dalam mobil yang sedang melaju. Melihat hal-hal tersebut, siswa-siswa ini sangat prihatin".

Berkaitan dengan hasil temuan, menunjukkan bahwa siswa menyampaikan hal mengenai apa yang dirasakannya untuk mendapatkan rasa empati dari penggiat lingkungan, sehingga penggiat lingkungan dapat merasakan apa yang sedang dirasakan siswa tentang perilaku orang yang tidak peduli lingkungan dalam hal pengelolaan sampah.Sikap empati yang ditunjukkan penggiat lingkungan dapat dirasakan siswa melalui jawaban yang diutarakan penggiat lingkungan sebagai reaksi dari pernyataan informan siswa. Reaksi tersebut yang merupakan sikap empati yang ditunjukkan oleh penggiat lingkungan kepada siswa.

\section{Pendukungan/Sikap Mendukung}

Hubungan antarpribadi yang efektif adalah terdapat usaha pemberian dukungan. Sikap suportif adalah sikap yang mengurangi sikap defensive dalam berkomunikasi. Orang dikatakan defensive bila tidak menerima, tidak jujur, dan tidak empatis. Hal ini tentu akan menggagalkan komunikasi antarpribadi. Artinya, bagaimana kita dapat berkomunikasi dengan orang yang perkataannya tidak dapat dipercaya. Orang yang tidak dipercaya karena perkataannya tidak jujur, ketika orang tidak jujur bagaimana orang tersebut dapat berempati bahkan dapat menerima pendapat orang lain. Pemberian dukungan ditunjukkan melalui usaha diri kita yang bersifat deskriptif daripada evaluative dan bersifat sementara daripada pasti.

Informan merasakan sikap suportif yang ditunjukkan oleh penggiat lingkungan dalam setiap komunikasi yang dilakukan, sehingga membangkitkan semangat siswa untuk melakukan pengelolaan sampah sehingga mampu untuk merubah perilaku siswa lebih peduli terhadap lingkungan dalam hal pengelolaan sampah. Seperti informan $\mathrm{Fa}$, yang dapat ditunjukkan dari hasil wawancara sebagai berikut:

“....bapak itu mendengarkan sekaligus memberi motivasi. Bapak itu selalu bilang, kita jangan serupa dengan orang yang perilakunya tidak baik tentang lingkungan, karena itulah harus menunjukkan sikap yang peduli lingkungan. Harus mulai dari diri sendiri".

Hasil temuan menunjukkan bahwa penggiat lingkungan memberikan pendukungan terhadap perasaan yang diungkapkan informan siswa berkaitan dengan pengelolaan sampah. Hal ini dapat dilihat dari sikap mendukung yang diberikan penggiat lingkungan dengan memberi motivasi kepada siswa untuk tetap menunjukkan sikap yang peduli lingkungan dengan mulai dari diri sendiri. Hasil wawancara dengan informan siswa Bs, sebagai berikut: 
"Bapak itu dengan sabar menasehati dan memberi motivasi supaya berbuat yang baik. Bapak itu sering bilang, kita jangan seperti orang lain yang perilakunya tidak baik, kita harus menunjukkan perilaku yang baik terhadap lingkungan supaya bisa jadi teladan bagi orang lain”.

Komunikasi yang dilakukan oleh penggiat lingkungan terhadap informan siswa Bs memperlihatkan bahwa sikap defensive yang dilakukan penggiat lingkungan telah memberi semangat dan menjadi motivasi bagi siswa supaya tidak ikut-ikutan dengan perilaku otang lain yang tidak peduli lingkungan. Sikap peduli lingkungan harus dimulai dari diri sendiri. Artinya, komunikasi yang dilakukan oleh penggiat lingkungan terhadap siswa dapat memberi motivasi bagi siswa sebagai sikap pendukungan yang diberikan oleh penggiat lingkungan. Hal ini dapat dilihat dari hasil wawancara terhadap informan Da, berikut ini:

“....kalau orang lain berbuat yang tidak baik, kita jangan ikut-ikutan, kalau ada orang yang tidak tahu, kita harus kasi tahu. Kalau ada orang yang tidak suka, kita harus tunjukkan sikap kita yang peduli lingkungan".

Pendukungan yang diberikan penggiat lingkungan terhadap siswa dapat dilihat dari hasil wawancara tersebut berkaitan dengan pengelolaan sampah. Komunikasi yang terbuka dan empati tidak dapat bertahan dalam suasana yang tidak mendukung. Keterbukaan yang dilakukan penggiat lingkungan dalam berkomunikasi untuk bereaksi secara jujur terhadap siswa tidak akan dapat bertahan tanpa sikap empati yang ditunjukkan oleh penggiat lingkungan kepada siswa dan demikian juga sebaliknya. Sikap terbuka dan empati yang ditunjukkan oleh masing-masing informan dalam berkomunikasi terhadap satu dengan yang lain dapat berlangsung dengan baik dan bertahan karena ada suasana pendukungan yang terjadi diantara mereka.

\section{Kepositifan/Sikap Positif}

Sikap positif dalam komunikasi antarpribadi disampaikan dengan menyatakan sikap yang positif dan memberikan pujian pengakuan (stroking). Komunikasi antarpribadi akan berkembang jika terdapat perhatian yang positif terhadap diri seseorang sendiri dan perasaan yang positif adalah penting untuk menjalin interaksi yang efektif. Sikap positif ini dapat ditunjukkan melalui sikap yang secara positif mendorong orang yang menjadi teman kita berinteraksi.

Temuan menunjukkan bahwa siswa telah memberikan sikap yang positif terhadap penggiat lingkungan dengan memberikan pujian terhadap penggiat lingkungan seperti yang diungkapkan informan Er, sebagai berikut:

"Menurutku..., mudah dimengerti apa yang disampaikan penggiat lingkungan, apalagi kalau tentang pengelolaan sampah".

Hal tersebut memperlihatkan bahwa informan Er menunjukkan sikap yang positif terhadap penggiat lingkungan sehingga memberikan pujian terhadap penggiat lingkungan dengan menyebutkan bahwa penggiat lingkungan "cara menyampaikannya bagus, menguasai betul dan sudah ahlinya". Artinya komunikasi antarpribadi yang dilakukan oleh penggiat lingkungan terhadap siswa memberikan perasaan positif bagi siswa terhadap penggiat lingkungan yang telah menjalin interaksi secara efektif terhadap siswa.

Kepositifan lebih ditunjukkan dengan cara memberi pujian pengakuan mengenai keberadaan seseorang yang memiliki arti penting. Pemberian pujian pengakuan dapat 
ditunjukkan dalam bentuk verbal seperti ucapan "saya senang berbicara dengan kamu" atau dalam bentuk nonverbal, seperti dengan memberikan senyuman. Temuan penelitian memperlihatkan bahwa informan Bs yang menyatakan bahwa keberadaan penggiat lingkungan memiliki arti penting disekolah, seperti hasil wawancara berikut:

"Menurut saya, yang disampaikan Bapak itu tentang pengelolaan sampah mudah dimengerti, cara menyampaikannya enak, kelihatan sekali Bapak itu ahlinya. Sejak Bapak itu ke sekolah ini, sekolah kami menjadi lebih bagus dalam pengelolaan sampah, lebih rapi, bersih, asri, nyaman, sejuk".

Hal ini dapat dilihat dari pengakuan yang telah diberikan informan siswa. Sikap positif yang ditunjukkan oleh informan siswa terhadap penggiat lingkungan dapat terjadi sebagai alibat dari sikap positif yang lebih dahulu dilakukan oleh penggiat lingkungan terhadap siswa, yakni dengan adanya komunikasi antarpribadi yang di lakukan dengan menunjukkan sikap secara positif mendorong siswa untuk berperilaku peduli lingkungan dalam hal pengelolaan sampah.

\section{Kesetaraan}

Kesetaraan tidak menuntut agar kita menerima atau menyetujui semua perilaku dari orang lain baik secara verbal dan nonverbal. Kesetaraan dalam hubungan antarpribadi berjalan dengan efektif harus mengakui kesetaraan kepribadian, sehingga kedua belah pihak adalah manusia yang berharga, berguna dan masing-masing memiliki sesuatu yang penting dapat disumbangkan dalam komunikasi. Hal ini bukan berarti tidak ada konflik atau ketidaksepahaman dalam berkomunikasi karena dalam situasi apapun, terdapat kemungkinan ketidaksetaraan.
Ketidaksepahaman atau konflik lebih dilihat sebagai upaya untuk memahami perbedaan yang pasti ada daripada sebagai kesempatan untuk menjatuhkan orang lain. Seseorang bisa saja lebih pintar, lebih menguasai suatu hal, atau lebih kaya. Berkaitan dengan kesetaraan, hasil temuan menunjukkan bahwa penggiat lingkungan tidak merasa dirinya adalah pribadi yang harus ditakuti karena pengalamannya dibidang pengelolaan sampah jauh lebih tinggi dari pengetahuan siswa.

Hal ini terlihat dari hasil wawancara terhadap siswa yang mengatakan bahwa penggiat lingkungan tersebut adalah orang yang mudah tersenyum, ramah, mau diajak bercanda, bahkan penggiat lingkungan lebih sering melakukan interaksi dengan siswa secara intens. Sehubungan dengan hal tersebut dapat dilihat dari hasil wawancara terhadap informan siswa An berikut:

“....Disitulah kami cerita-cerita tentang pengelolaan sampah, dimana kekurangannya, apa yang harus kami lakukan selanjutnya. Sambil ketawaketawa bercanda dan senda gurau".

$\begin{array}{cccc}\text { Pernyataan } & \text { informan } & \text { An tidak } \\ \text { berbeda dengan informan } & \text { Da } & \text { yang }\end{array}$ mengatakan bahwa penggiat lingkungan sering berinteraksi dengan informan dalam hal pengelolaan sampah. Berinteraksi, artinya berkomunikasi secara timbal balik antar penggiat lingkungan dan siswa. Interaksi yang dilakukan penggiat lingkungan melalui kesetaraan yang dirasakan oleh siswa telah mampu menunjukkan komunikasi antarpribadi yang dilakukan oleh penggiat lingkungan terhadap siswa berjalan dengan baik. Hal ini sesuai dengan hasil wawancara terhadap informan Da, berikut:

$\begin{array}{llr}\text { “....kami cerita-cerita } & \text { tentang } \\ \text { pengelolaan sampah kami. } & \text { Kalau } \\ \text { ngomong sama kami sering diajak }\end{array}$


becanda. Bapak itu ramah, mudah senyum, enaklah sama Bapak itu”.

$\begin{array}{crr}\text { Hasil } & \text { wawancara } & \text { tersebut } \\ \text { memperlihatkan } & \text { bahwa } & \text { penggiat }\end{array}$
lingkungan bersedia untuk cerita-cerita dengan siswa tentang pengelolaan sampah. Artinya, penggiat lingkungan menunjukkan sikap yang membuat siswa merasa nyaman untuk berkomunikasi dengan apa adanya. Hal ini dapat dilihat dari pernyataan informan siswa An dan Da bahwa penggiat lingkungan ramah dalam berkomunikasi bahkan sering bercanda kepada mereka sehingga menimbulkan perasaan bahwa keberadaan penggiat lingkungan setara dengan siswa dalam hal pengelolaan sampah.

Kesetaraan yang ditunjukkan oleh penggiat lingkungan terhadap siswa dapat dilihat dari sikap penggiat lingkungan yang mau mendengarkan cerita informan siswa tentang pengelolaan sampah. Perasaan setara yang ditunjukkanoleh penggiat lingkungan terhadap siswa telah menumbuhkan komunikasi antarpribadi yang terjadi antara mereka melalui canda yang dilakukan oleh penggiat lingkungan.

\section{Analogi Bawang}

Hasil temuan menunjukkan bahwa cara penggiat lingkungan memulai komunikasi terhadap siswa adalah dengan melakukan sosialisasi terhadap seluruh siswa di sekolah. Tahap ini, penggiat lingkungan memperkenalkan dirinya serta menyatakan tujuan sosialisasi ini. Melalui sosialisasi yang dilakukan penggiat lingkungan mulai memperhatikan siswa yang menunjukkan respon terhadap kegiatan ini, sehingga pada pertemuan selanjutnya penggiat lingkungan sudah dapat berkomunikasi secara antarpribadi terhadap siswa. Hal ini dapat dilihatsesuai hasil wawancara terhadap penggiat lingkungan, sebagai berikut:
"Awalnya, saya berkomunikasi secara keseluruhan melalui sosialisasi tentang lingkungan khususnya pengelolaan sampah. Melalui sosialisasi tersebut saya sampaikan bagaimana tentang pengelolaan sampah yang baik dan benar. Setiap pertemuan yang saya lakukan, saya memperhatikan reaksi siswa-siswa di sekolah ini. Seiring waktu berjalan, saya menemukan beberapa siswa yang memahami tentang pengelolaan sampah".

Tahap perkenalan dapat berlanjut kepada tahap yang lebih dalam dan lebih dekat lagi apabila ada respon dan tanggapan dari pihak lawan bicara, dalam hal ini adalah siswa. Penggiat lingkungan dapat melanjutkan untuk berkomunikasi secara antarpribadi kepada siswa setelah pertemuan berikutnya ketika melihat ada reaksi dari siswa tentang kegiatan pengelolaan sampah. Tahap ini sudah terjadi balas-balasan antara penggiat lingkungan dengan siswa yaitu dengan menanyakan kembali nama dari siswa yang diajak berkomunikasi secara antarpribadi.

Hasil temuan memperlihatkan bahwa ketika penggiat lingkungan menanyakan nama siswa dan mengingatnya dengan memanggil nama siswa tersebut telah menunjukkan perasaan senang bagi siswa karena merasa bahwa penggiat lingkungan hafal nama siswa tersebut seperti hasil wawancara terhadap informan siswa An, berikut:

"Pak Paris sering datang ke sekolah kak, awalnya tanya nama, hobbi, alamat, kemudian pelajaran yang disukai sampai ngobrol panjang lebar. Cerita dengan Pak Paris, saya merasa nyambung dan enak ngobrolnya karena bapak itu ramah, mudah senyum, dan cepat akrab. Kadang-kadang bapak itu bawa bibit pohon untuk ditanam. Kalau Bapak itu datang kamudian, ditanyalah 
sudah bagaimana bibit yang ditanam itu, apa saja yang sudah dilakukan terhadap bibit pohon itu, sudah di pupuk kah. Berbeda dengan penggiat lingkungan lain yang sudah pernah datang ke sekolah".

Hasil wawancara tersebut menunjukkan bahwa penggiat lingkungan melakukan komunikasi antarpribadi dengan menggunakan lapisan kulit bawang mulai dari tahap datang ke sekolah, melakukan sosialisasi, kemudian bertanya kepada siswa mulai dari nama, hobbi, alamat, dan pelajaran yang disukai siswa sampai cerita tentang pengelolaan sampah sehingga menimbulkan perasaan senang bagi siswa terhadap penggiat lingkungan. Komunikasi antarpribadi yang dilakukan penggiat lingkungan terhadap siswa, ada lapisanlapisan yang dilalui oleh penggiat lingkungan untuk dapat menarik perhatian siswa sehingga komunikasi tersebut menjadi sesuatu hal yang menyenangkan bagi mereka.

Hasil wawancara ini memperlihatkan ada lapisan kulit bawang yang dilakukan oleh penggiat lingkungan yang dimulai dengan kegiatan sosialisasi pengelolaan sampah, kemudian sering berkunjung ke sekolah, membawa bibit pohon untuk ditanam di sekolah, menanyakan hasil dari bibit pohon yang ditanam, agar disiram, dipupuk, dan menanyakan bagaimana hasilnya. Komunikasi antarpribadi yang dilakukan penggiat lingkungan terhadap siswa telah mampu menembus lapisan kepribadian siswa sebagai lapisan bawang kehidupannya, sehingga menumbuhkan rasa ketertarikan siswa terhadap kegiatan pengelolaan sampah.

Sedikit berbeda dengan informan sebelumnya, informan siswa Er mengatakan bahwa dirinya mulai mengenal penggiat lingkungan pada saat penggiat lingkungan berkunjung pada kunjungan berikutnya.
Ada perasaan senang yang ditunjukkan oleh siswa ketika penggiat lingkungan bertanya bagaimana kabarnya, bagaimana pelajarannya, bahkan penggiat lingkungan membawa bibit pohon untuk di tanam di sekolah, kemudian setiap pertemuan ada tindak lanjutnya berkaitan tentang pengelolaan sampah.

Hal ini menunjukkan bahwa penggiat lingkungan melakukan komunikasi antarpribadi dengan melalui lapisan kulit bawang pada tahap perkenalan. Hasil wawancara terhadap informan siswa Er, dapat dilihat sebagai berikut:

"Bapak itu sering datang ke sekolah kak, tanya kabar kami trus kekmana pelajaran kami, kadang-kadang bapak itu bawa bibit pohon juga kak supaya kami tanam. Kalau Bapak itu datang, ditanyalah sudah kekmana bibit yang kami tanam itu, apa saja yang sudah kami lakukan terhadap bibit pohon itu".

Hasil wawancara tersebut menunjukkan bahwa penggiat lingkungan melakukan komunikasi antarpribadi melalui kegiatan pengelolaan sampah yang dimulai dari kunjungan ke sekolah yang sering dilakukan, kemudian bertanya tentang kabar siswa, bagaimana pelajarannya. Hal ini menumbuhkan rasa senang bagi siswa karena diperhatikan sehingga ada keinginan untuk terus berkomunikasi terhadap penggiat lingkungan. Komunikasi yang dilakukan penggiat lingkungan tersebut telah melewati lapisan-lapisan kepribadian dari kehidupan siswa.

\section{Hambatan-Hambatan Dalam \\ Berkomunikasi}

Hasil temuan menunjukkan bahwa yang menjadi hambatan penggiat lingkungan dalam berkomunikasi terhadap siswa dapat dilihat sesuai hasil wawancara terhadap penggiat lingkungan berikut: 
"Sebenarnya tidak banyak, tetapi ada satu hal yang lucu bagi saya, yaitu ketika saya bertemu dengan siswa-siswa tersebut, saya berbicara dengan logat suku karo (sambil tersenyum). Saya melihat mereka tersenyum satu dengan lain. Pernah ada hal yang menjadi hambatan bagi saya, yaitu ketika saya harus mengucapkan istilah Bahasa Inggris, saya tidak begitu paham mengucapkannya".

Hasil wawancara tersebut memperlihatkan bahwa dalam berkomunikasi terhadap siswa ada hambatan yang dihadapi penggiat lingkungan, yaitu dalam bentuk gangguan semantik yang berkaitan dengan penggunaan bahasa dalam isitilah asing seperti reduce, reuse, dan recycle. Pengucapan yang salah terhadap istilah ini akan menimbulkan pengertian yang salah bagi siswa sehingga komunikasi tidak berjalan dengan efektif. Penggunaan logat bahasa daerah juga merupakan hambatan semantik yang dihadapi penggiat lingkungan yakni dengan menggunakan logat/dialek bahasa suku karo yang merupakan suku dari penggiat lingkungan.

Temuan penelitian menunjukkan bahwa ke-enam informan siswa juga mengatakan hal yang sama berkaitan dengan hambatan yang terjadi antara penggiat lingkungan terhadap siswa dalam berkomunikasi tentang pengelolaan sampah tidaklah begitu signifikan namun dapat menjadi hambatan yang membuat komunikasi menjadi tidak efektif. Hambatan tersebut berupa penggunaan bahasa dalam bentuk logat/dialeg bahasa daerah dari penggiat lingkungan seperti yang diungkapkan informan siswa Bs dalam wawancara berikut:

"Penggunaan bahasa yang diucapkan penggiat lingkungan seperti istilah reduce, reuse, dan recycle. Sering terbalik pengucapannya sehingga pengertian berbeda".

Hasil wawancara tersebut menunjukkan bahwa, ada salah pengertian terhadap pengucapan yang diucapkan oleh penggiat lingkungan mengenai suatu istilah dalam penggunaan bahasa, sehingga dapat menimbulkan salah pengertian bagi siswa. Informan siswa $\mathrm{Fa}$ juga mengatakan hal yang sama bahwa dirinya tidak dapat mengerti ketika penggiat lingkungan mengucapkan istilah dalam bahasa Inggris yang kurang tepat yaitu dalam megucapkan kata reduce, reuse, dan recycle, seperti dari hasil wawancara terhadap informan siswa Fa, berikut ini:

"Pengucapan istilah dalam bahasa Inggris, yang disampaikan penggiat lingkungan misalnya mengucapkan istilah reduce, reuse, dan recycle yang kurang tepat sehingga menimbulkan salah pengertian".

Informan penggiat lingkungan juga mengatakan bahwa dirinya terkadang keceplosan dengan logat karo sehingga membingunggkan siswa dan pengucapan istilah dalam Bahasa Inggris, seperti mengucapkan istilah reduce, reuse, dan recycle kurang tepat, sehingga menimbulkan salah pengertian terhadap siswa. Berarti, yang di ungkapkan ke-enam informan tersebut adalah benar adanya. Hal inilah yang merupakan hambatan dalam berkomunikasi bagi penggiat lingkungan terhadap siswa. Kelihatannya hambatan dalam berkomunikasi penggiat lingkungan terhadap siswa tidak banyak, namun sekecil apapun hambatan tersebut harus diupayakan untuk mengatasinya.

\section{KESIMPULAN}

Ada beberapa hal yang dapat diuraikan sebagai berikut:Penggiat lingkungan melakukan komunikasi 
antarpribadi secara efektif terhadap siswa dalam mengubah perilaku pengelolaan sampah siswa. Keefektifitasan komunikasi antarpribadi yang dilakukan oleh penggiat lingkungan terhadap siswa dikembangkan melalui kualitas diri yang mencakupKeterbukaan, Empati, Pendukungan/Sikap Mendukung, Kepositifan/Sikap Positif, Kesetaraan.

Kepribadian manusia juga merupakan hal yang serupa dengan lapisan bawang, ada lapisan yang ditemukan ketika kita mulai berkomunikasi. Tahap perkenalan merupakan hal yang disebut sebagai permulaan, tentu perkenalan dimulai dengan kontak. Perkenalan tidak mungkin tercapai tanpa adanya kontak terlebih dahulu. Artinya, ada komunikasi antarpribadi yang terjadi antara masingmasing pihak. Kontak dapat terjadi dengan adanya pertemuan antara pelaku komunikasi. Perkenalan kemudian berlanjut pada tahap keterbukaan dan kejujuran. Tahap inilah yang disebut dengan lapisan bawang.

Hambatan bagi informan penggiat lingkungan terhadap informan siswa adalah gangguan yang sifatnya sebagai gangguan semantik melalui penggunaan bahasa dan pengertian suatu istilah atau konsep yang terdapat pada informan penggiat lingkungan, sehingga gangguan ini terjadi menyebabkan salah pengertian antara informan penggiat lingkungan dan informan siswa.

\section{DAFTAR PUSTAKA}

Convelo G. Cevilla. (1993). Pengantar Metode Penelitian. Jakarta: Universitas Indonesia.

Effendy, Onong Uchjana. (2007). Ilmu Komunikasi Teori dan Praktek. Bandung: Penerbit Remaja Rosdakarya.
Harapan Edi dan Syarwani Ahmad, (2014). Komunikasi Antarpribadi: Prilaku Insani Dalam Organisasi Pendidikan. Penerbit PT. RajaGrafindo Persada cetakan kesatu. Jakarta.

Rakhmad, Jalaluddin. (2004). Psikologi Komunikasi. Bandung: PT. Remaja Rosdakarya.

Soemarwoto, Otto. (1991). Ekologi Lingkungan Hidup dan Pembangunan. Jakarta: Djambatan.

West, R. \& Turner. L. (2011). Pengantar Teori Komunikasi Analisis dan Aplikasi. Edisi 3. Jakarta: Penerbit Salemba Humanika.

\section{Sumber non buku/majalah:}

Undang - Undang Nomor 18 Tahun 2008 tentang Pengelolaan Sampah

Peraturan PemerintahNomor 81 Tahun 2012 Tentang Pengelolaan Sampah Rumah Tangga dan Sampah Sejenis Sampah Rumah Tangga 